\title{
Re-Imagining the Concept of Forced Migration in the Face of Cli- mate Change
}

\author{
Allan M Mukuki* \\ DOI: $10.21827 / 5 \mathrm{~d} 5141 \mathrm{~d} 53 \mathrm{f} 710$

\section{Keywords} \\ CLIMATE CHANGE; CLIMATE MIGRANTS; REFUGEES, PERSECUTION
}

\begin{abstract}
This article analyses the impacts of climate change which are no longer only within the scientific realm. This analysis reveals the effects of climate change and the challenges that it poses to the current refugee definition and the existing regime of refugee protection in international law. An all-inclusive refugee definition under international law, to include climate change as a Convention ground for people to seek refugee status is argued for herein. Judicial expansion of the definition and the development of soft law principles to cater for climate migrants is also discussed. Nevertheless, it is also noted that there exist numerous challenges in the re-imagination of the concept of forced migration in the face of climate change. Political considerations as well as a lack of State will and consensus on the existence of climate migrants have been the most visible challenges yet.
\end{abstract}

\section{Introduction}

From desertification to rising temperatures and even sinking islands, climate change and the effects thereof are visible to all. ${ }^{1}$ While predictions vary, climate change is expected to contribute to the displacement of millions of people. ${ }^{2}$

Allan M Mukuki is a PhD Candidate at Leiden Law School. He is the holder of an LL.M. in International Law and the Law of International Organisations from the University of Groningen, LL.B. (Hons) from the University of Nairobi, School of Law, as well as an Associate of the Chartered Institute of Arbitrators (ACIArb). He is also a holder of a post-graduate diploma in law from the Kenya School of Law. Presently, he is an Advocate of the High Court of Kenya as well as a lecturer of International Law in Strathmore Law School. This article was developed with the able assistance in editing by Raphael Ng'etich, LL.B. (Hons), Strathmore University Law School and Francis Njoroge.

Lauren Nishimura, 'Climate Change Migrants': Impediments to a Protection Framework and the Need to Incorporate Migration into Climate Change Adaption Strategies' (2015) 27 International Journal of Refugee Law 107. See also Frank Laczko and Christine Aghazarm, Migration, Environment and Climate Change: Assessing the Evidence (IOM 2009) 9-11; Martin Parry and others (eds) Climate Change 2007: Impacts, Adaptation and Vulnerability (IPCC 2007) 13, 35, 110; Thomas Stocker and others (eds), Climate Change 2013: The Physical Science Basis (Contribution of Working Group I to the Fifth Assessment Report of the Intergovernmental Panel on Climate Change, IPCC 2013) 4-12; The Paris climate conference (COP21) in December 2015, 195 countries adopted the first-ever universal, legally binding global climate deal (to come into effect in 2020) which sets out a global action plan to put the world on track to avoid dangerous climate change by limiting global warming to well below $2^{\circ} \mathrm{C}$, signifying the dire effects of climate change.

Nishimura (n 1) 108; Angela Williams, 'Turning the Tide: Recognizing Climate Change Refugees in International Law' (2008) 30 Law \& Policy 502, 506 (noting that estimates for climate change displacement range from 50-200 million by 2080); C Beyani, 'Report of the Special Rapporteur on the human rights of internally 
Despite this reality, little to no research has been undertaken to address the resulting increase in migration. At present, no international agreement exists that explicitly accounts for climate-induced migrants ('climate migrants')., ${ }^{3}$ nor is there academic consensus on whether climate migrants really exist. ${ }^{4}$ Debate has long been centred on whether climate migrants can be considered under the definition of a refugee as provided by international and regional conventions and, if so, how to expand existing international refugee law to encompass climate migrants. Proposed solutions and calls for action are yet to produce meaningful agreement on how to proceed. ${ }^{5}$ Instead, States and international decision-makers are at an impasse, and legal gaps in the protection of these refugees remain.

This article first examines the refugee definition in the Convention Relating to the Status of Refugees of 1951 (1951 Convention), which is the key legal document in defining who is a refugee, their rights and the legal obligations of States. This analysis is focused on the question of whether climate migrants are provided for among the various classes of refugees protected by the 1951 Convention.

Assuming that climate migrants are not catered for in the existing international legal framework, this article questions whether they should be included and who would fall under such a category. Alternatively, should a whole new framework be created for them? A critical assessment of the obstacles such an effort would face is undertaken in the second part of this article.

An analysis of existing situations of climate migrants and of literature on this topic forms the basis of this article. Questions that are analysed herein include: how many have migrated due to climate change? Where have they migrated to? Has the migration been temporary or permanent, internal or international? $?^{6}$

The main contribution of this article is to show that the refugee definition as developed in 1951 (just after World War II) has, over time, failed to provide for new developments in refugee situations and particularly for environmental migrants. The research suggests that, just as climate change has become a great phenomenon in today's world, the environmental migrants that it produces should be protected under the existing regime of international refugee law.

displaced persons' (9 August 2011) UN Doc A/66/285 (citing IPCC estimate that climate change could displace 150 million by 2050).

The closest one is the Paris Agreement (n 1) but note that this agreement is only dealing with curbing climate change and not climate-induced immigrants.

$\mathrm{J}$ Barnett and $\mathrm{M}$ Webber, 'Accommodating Migration to Promote Adaptation to Climate Change' (Commission on Climate Change and Development 2009) <https://www.unisdr.org/files/11872_AccommodatingMigration1.pdf > accessed 11 May 2019.

For example, while the issue of migration entered into United Nations Framework for Climate Change Convention (UNFCCC) discussions and draft negotiations text in 2008, and was included in the Cancun Adaptation Framework in 2010, further concrete action or incorporation of migration induced by climate change under the UNFCCC or into regional and international planning has stalled. See Koko Warner, 'Climate and environmental change, human migration and displacement: Recent policy developments and research gaps' (UN/POP/MIG-9CM/2011/10, UNU-EHS 12 February 2011) 4 (outlining initial mobilization of the humanitarian community and subsequent UNFCCC delegate and Party discussions that brought migration issues into the UNFCCC climate change negotiations process); See Nishimura, (n 1) 2. 


\section{Climate Migrants and Their Status under Current International Refugee Law}

In a bid to understand who is a 'conventional refugee', it is prudent to look at the context of the 1951 Convention; therein lies the conundrum faced by climate migrants, as climate change has greatly tilted the scales in modern times particularly in the context of forced migration.

\section{I.II Context of the 1951 Refugee Convention}

The history of international refugee protection began with the League of Nations, with the International Committee of the Red Cross (ICRC) being the "initiator of the international protection system set up by the League of Nations. ${ }^{7}$

World War I, its preliminaries and its aftermath in the Near East caused considerable upheavals in the States involved and especially in the Russian Empire. ${ }^{8}$ Large numbers of refugees left Russian territories for various countries of Europe or Asia Minor, Central and East Asia between 1918 and $1922 .{ }^{9}$ Emergency relief was provided, mainly by charitable organisations. However, these organisations could not extend their support beyond material assistance..$^{10}$ This prompted the Joint Committee of the International Committee of the Red Cross and the League of Red Cross Societies to call a conference of the principal organisations concerned, where it was decided to invite the Council of the League of Nations to appoint a High Commissioner to define the status of refugees, secure their repatriation or employment outside Russia and coordinate measures for their assistance. ${ }^{11}$

Tragic events in the Ottoman Empire had affected various ethno-religious communities long before World War I. ${ }^{12}$ Therefore, in order to protect and assist the refugees from the Ottoman Empire, the mandate of the High Commissioner of the League of Nations was extended from Russian Refugees to Armenians in 1924 and to 'other categories of refugees' (Assyrians, Syrians, Kurds and a small group of Turks) in $1928 .{ }^{13}$ These institutions afforded international protection to refugees on the basis of international legal instruments generally concluded within the framework of the League of Nations, such as the Convention Relating to the International Status of Refugees of 28 October 1933. ${ }^{14}$

The 1933 Convention became a pivotal instrument in international refugee law. It dealt with issues such as legal questions, labour conditions, welfare and relief, education and exemption from reciprocity. It also provided for the creation of committees for refugees. Most

Gilbert Jaeger, 'On the History of the International Protection of Refugees' (2001) 83 International Committee of the Red Cross 727.

ibid.

ibid.

ibid.

John Simpson, ‘The Refugee Problem' (OU, 1939) 199.

Jaeger (n 7) 729.

ibid.

ibid. 
importantly, it elevated the principle of non-refoulement to the status of international treaty law. In addition, the 1933 Convention served as a model for the 1951 Convention. ${ }^{15}$

A further international instrument of that period is the resolution which the Intergovernmental Committee on Refugees (IGCR) adopted on 14 July 1938 in Evian to define its functions. ${ }^{16}$ This resulted in protection being extended, for the first time, to would-be refugees inside the country of potential departure.

The next phase in international protection was the creation of the International Refugee Organisation (IRO) ${ }^{17}$ The IRO was established in 1946 through a UN Resolution of the United Nations General Assembly. It became widely known as 'the resettlement agency', as its principal activity was the resettlement of refugees and displaced persons. ${ }^{18}$ It was intended to wind up its operations in June 1950, however, it became evident that the refugee problem would not be solved by that date. Therefore, the Commission of Human Rights adopted a Resolution expressing the wish that early consideration be given by the United Nations (the UN) to the legal status of persons who do not enjoy the protection of any government, in particular pending the acquisition of nationality, as regards their legal and social protection and their documentation. ${ }^{19}$

On the basis of the aforementioned Resolution and a request by the Economic and Social Council, the Secretary General, in consultation with interested commissions and specialised agencies, undertook a study that resulted in 'A Study of Statelessness' ('the Study'), a key document in the more modern history of international refugee protection. ${ }^{20}$ The Study examined in detail various aspects of the 'state of stateless persons' (which includes refugees).$^{21}$ The main elements of the 1951 Convention can be found in the Study, which also very clearly shows the derivation of the 1951 Convention from the pre-war conditions. ${ }^{22}$

The Study also elaborated on 'the organ responsible for protection' and discussed the merits of the type of international organ required, among them continuance of the IRO, albeit in another form. ${ }^{23}$ Having considered the Study, the Economic and Social Council appointed,

ibid, 730; See Article 3 of the Convention relating to the International Status of Refugees of 28th October 1933, 'Each of the Contracting Parties undertakes not to remove or keep from its territory by application of police measures, such as expulsions or non-admittance at the frontier (refoulement), refugees who have been authorised to reside there regularly, unless the said measures are dictated by reasons of national security or public order. It undertakes in any case not to refuse entry to refugees at the frontiers of their countries of origin. It reserves the right to apply such internal measures as it may deem necessary to refugees who, having been expelled for reasons of national security or public order, are unable to leave its territory because they have not received, at their request or through the intervention of institutions dealing with them, the necessary authorisations and visas permitting them to proceed to another country.'

T Sjoberg, The Powers and the Persecuted: The Refugee Problem and the Intergovernmental Committee on Refugees (IGCR) 1938 - 1947 (Lund University Press 1991).

Jaeger (n 7) 732.

ibid.

See, Supplement 1 to the Economic and Social Council Official Records 1946, 13-14; See also Jaeger (n 7) 732-3.

Jaeger (n 7) 732-3; See UN Ad Hoc Committee on Refugees and Stateless Persons (UNHCR), 'A Study of Statelessness' (United Nations, Lake Success, New York, 1 August 1949) <https://www.unhcr.org/protection/statelessness/3ae68c2d0.org> accessed 11 May 2019.

UNHCR (n 20).

Jaeger (n 7) 734.

ibid. 
on 8 August 1949, an ad hoc committee on Refugees and Stateless Persons to 'consider the desirability of preparing a revised and consolidated convention relating to the international status of refugees and stateless persons and draft the text of such a convention' ${ }^{24}$ The Council's intention was that a final draft of the Convention be approved by the UN General Assembly. ${ }^{25}$ A conference was convened in December 1950 to sign the convention, which was then adopted in July 1951. The UN General Assembly also decided in December 1949 to establish, as of 1 January 1951, a High Commissioner's Office for Refugees and, on 14 December 1950, the Statute of the Office of the United Nations High Commissioner for Refugees was adopted.

Since that period, a growing number of States have ratified and implemented the 1951 Convention and its 1967 Protocol. ${ }^{26}$ Furthermore, regional organisations have developed their own conventions, such as the Organisation of African Unity's Convention Governing the Specific Aspects of Refugee Problems in Africa of 1969 (OAU Convention), which modifies the definition of who exactly is a refugee in the African context, in addition to the requirements provided for in the 1951 Convention. The current situation is that refugee law has become an important part of the world; it is inevitable that there will be refugees in one way or another. Thus, the question that should be answered is this: who exactly is a refugee?

\section{I.II Refugee Definition}

A refugee is defined as:

... any person, who, owing to a well-founded fear of being persecuted for reason of race, religion, nationality, membership of a particular social group or political opinion, is outside the country of his nationality and is unable or owing to such fear, is unwilling to avail himself of the protection of the country. ${ }^{27}$

The threshold of a 'well-founded fear of persecution' is that which is reasonably possible to face persecution on return. This issue of persecution is dealt with later in this article.

It must be noted that the Article 1(3) of the 1967 Protocol Relating to the Status of Refugees ${ }^{28}$ removes the geographical and temporal restrictions that had hitherto existed under the 1951 Convention. The 1951 Convention had restricted refugee status to those who were considered so 'as a result of events occurring before 1 January 1951', as well as giving State parties to the Convention the option of interpreting this as 'events occurring in Europe' or 'events occurring in Europe or elsewhere', the 1967 Protocol removed both the temporal and geographic restrictions.

See ECOSOC Resolution 248 (IX); UNHCR (n 20); See also Jaeger (n 7) 735.

Jaeger (n 7) 735.

The UN Convention relating to the Status of Refugees is the key international legal document relating to refugee protection. It defines who is a refugee and outlines the rights of refugees and the legal obligations of States towards refugees. It also underpins the work of UNHCR. There are currently 144 States Parties to the 1951 Convention and 145 to its 1967 Protocol, with 142 States Parties to both the Convention and Protocol; See UNHCR, 'States Parties to the 1951 Convention relating to the Status of Refugees and the 1967 Protocol' (June 2014) <http://www.unhcr.org/3b73b0d63.html> accessed 11 May 2019.

Convention Relating to the Status of Refugees (adopted 28 July 1951, entered into force 22 April 1954) 189 UNTS 137 art 1(a)(2).

Protocol Relating to the Status of Refugees (adopted 31 January 1967, entered into force 4 October 1967) 606 UNTS 267 (Protocol). 
The refugee definition provided under the 1951 Convention has been subsequently expounded in the 1969 OAU Convention to include people fleeing external aggression, internal civil strife, or events seriously disturbing public order in African countries. ${ }^{29}$ The OAU Convention thus enabled millions of people in need of protection to be covered and assisted with greater legal and operational facility in Africa and other parts of the world where the Convention has inspired similar legal developments or applications of refugee law. ${ }^{30}$ In addition, this unique definition explicitly introduces objective criteria, based on the conditions prevailing in the country of origin, for determining refugee status and requires 'neither the elements of deliberateness nor discrimination inherent in the 1951 Convention'. ${ }^{31}$

This definition has been further expanded by other regional instruments, such as the Montevideo Treaty of 1889 , which includes political asylum seekers as refugees, ${ }^{32}$ and the Cartagena Declaration of 1984, which also includes internal conflicts (aggression) as a reason for the fear of persecution. ${ }^{33}$ This, in essence, expands the OAU Convention definition which caters for external aggression.

An examination of the definition of a refugee provides the first angle of refugee protection, as it ensures that only people fitting into a particular description protection can be ed under the Conventions and national laws. At face value, this would not seem to be a protection angle, however. Closer examination reveals that the definition identifies who exactly a refugee is; otherwise without it, there would be situations where every person who felt the need to move to another country, or who was simply not satisfied with the living conditions in their country, or even fugitives, would be able to use refugee law as an avenue of escaping. However, refugee status is not permanent, meaning that the protection extended to a person who meets the criteria in the definition has a limited life-span. ${ }^{34}$ Hence, an emerging issue regarding the definition of a refugee concerns those who are fleeing countries which are slowly ceasing to exist, such as pacific countries which are sinking. Such people currently do not fall within any of the categories of persecution. This article discusses below whether climate-induced migrants are protected by existing regimes of refugee protection and, if not, what should be done.

The Organization of African Unity Convention: Governing Specific Aspects of Refugee Problems in Africa (adopted 10 September 1969, entered into force 20 June 1974) 10 UNTS 45 art 1(2).

Fatoumata Lejeune-Kaba, 'OAU Convention remains a key plank of refugee protection in Africa after 40 years' (2009) <http://www.unhcr.org/4aa7b80c6.html> accessed 11 May 2019.

See R Mandal, 'Protection Mechanisms Outside the 1951 Convention ("Complementary Protection")' (2005) UNHCR <https://www.unhcr.org/protection/globalconsult/435df0aa2> accessed 11 May 2019; See also M Sharpe, 'Analytical Overview of the 1969 (OAU) Convention for the SRLAN' Rights in Exile Programme $<$ www.refugeelegalaidinformation.org/african-union-refugee-definition> accessed 11 May 2019; See also E Arbodela, 'The Refugee Definition in Africa and Latin America: The Lessons of Pragmatism' 3 International Journal of Refugee Law 185, 192.

Treaty on International Penal Law (23 January 1889) art 16.

Cartagena Declaration on Refugees, Colloquium on the International Protection of Refugees in Central America, Mexico and Panama (22 November 1984) art 3(3).

Convention Relating to the Status of Refugees (n 27) art 1(c)(5). 


\section{I.III What are the Criteria for one to be Considered a Refugee?}

The refugee definition, as quoted, elicits three conditions that must be met for one to be considered a refugee:

a) Alienage: 'is outside the country of his nationality';

b) Persecution and the grounds thereof;

c) Well-founded fear

These three grounds are assessed individually below and the case of climate-induced migrants is analysed, with the aim of ascertaining whether they meet the conditions.

\section{a) Alienage: 'Is Outside the Country of His Nationality'}

A claimant of refugee status must be outside of their country of origin..$^{35}$ Basically, one must have crossed an international border so as to enjoy the benefit of claiming such status. ${ }^{36}$ This form of departure does not require an external factor (in this context, any form of persecution) to necessitate it. The decisive factor is the assessment of the 'fear' of persecution in the form of a 'forward looking apprehension of risk. ${ }^{37}$ The well-founded nature of this fear is discussed below.

\section{b) Persecution and the Grounds Thereof}

Although the requirement to show a well-founded fear of 'being persecuted' is at the core of the refugee definition, the 1951 Convention does not define persecution and neither does any other document. ${ }^{38}$ The ordinary meaning of persecution from the Oxford Dictionary is 'hostility and ill-treatment, especially because of race or political or religious beliefs; oppression' ${ }^{39}$ Persecution is also defined as 'the sustained or systematic violation of basic human rights. ${ }^{40}$

The 1951 Convention simply uses the words '[...] life or freedom was/would be threatened [...]'41 to indicate the nature of persecution. This fear of persecution must be individualized, as seen in Article 1(A) and (C) of the 1951 Convention. In dissecting the term 'fear of persecution', the United States Supreme Court ${ }^{42}$ determined that 'fear does not have to be realized

In essence, a refugee must be without the privilege of protection of a third State; See Guy Goodwin-Gill The Refugee in International Law (OUP 2007) 63; See NAGV and NAGW of 2002 v. Minister for Immigration and Multicultural Affairs (2005) HCA 6 where the Australian courts concurred with the Australian Government's position that Australia does not 'owe protection obligations' to asylum seekers who would be 'adequately protected in a safe third country' to which they can go; See S Taylor, 'Protection Elsewhere/Nowhere' (18 International Journal of Refugee Law 2006) 283; See also J Hathaway and M Foster, The Law of Refugee Status (CUP 2014) 17.

Goodwin-Gill (n 35) 63.

Hathaway and Foster (n 35) 105.

"There is no universally accepted definition of 'persecution', and various attempts to formulate such a definition have met with little success": UNHCR 'Handbook on Procedures and Criteria for Determining Refugee Status under the 1951 Convention and the 1967 Protocol relating to the Status of Refugees' (December 2011) UN Doc HCR/IP/4/Eng/REV.3, para 51; See also A Grahl-Madsen, 'The Status of Refugees in International Law' (1966) 1, 193; See also J Hathaway and M Foster, (n 35) 182. Oxford English Dictionary Online (OUP 2019) <en.oxforddictionaries.com/definition/persecution> (accessed 11 May 2019).

Convention Relating to the Status of Refugees, (n 27) art 31 and 33. Immigration and Naturalization Service v Cardoza-Fonseca 480 US 421 (1987), 430; See also INS v. Stevic 467 US 407 (1984) 422. 
... probability is enough... it does not have to be actualized. ${ }^{43}$ The Court was of the view that a refugee claimant 'need not prove that it is more likely than not that he or she will be persecuted in his or her home country', the probability of the same happening is enough. ${ }^{44}$

The 1951 Convention identifies five grounds of persecution which have correspondingly developed in the field of non-discrimination. ${ }^{45}$ This linkage to discrimination has been considered a necessary element of persecution; however, this article will not delve into that discussion. ${ }^{46}$

\section{i. $\quad$ Race}

With regard to race, account should be taken of Article 1 of the International Convention on the Elimination of All Forms of Racial Discrimination of 1965 (ICERD) which defines race to include distinctions based on 'race, colour, descent, or national or ethnic origin. ${ }^{47}$ It must be noted that the broad interpretation of the term 'race' includes groups defined by ethnicity as well as real or perceived physical or cultural distinctiveness of their members. 'Racial persecution' frequently leads to large scale persecutions. For instance, apartheid in South Africa ${ }^{48}$ and the Rwandan Genocide ${ }^{49}$ which was a result of the Hutus versus the Tutsis.

This test was established by the Supreme Court of the United States in Immigration and Naturalization Service (INS) v Cardoza-Fonseca 480 US 421 (1987) 440 per Stevens J; This phrasing was approved by the Supreme Court of Canada in Chan v Canada 3 SCR 593 (1995), para 120 which saw no material difference between this standard and 'serious possibility," and also by the High Court of South Africa in Tantoush v. Refugee Appeal Board ZAGPHC 191 (2007) para 97.

INS v Cardoza-Fonseca (n 42) 449; See also $R v$. Secretary of State for the Home Department, Ex parte Sivakumaran 3 WLR 1047 (1987) 994, per Lord Keith; See also HJ (Iran) v Home Secretary UKSC 31 (2010) para 89 per Lord Walker; See also Kwiatkowsky v. Canada (Minister of Employment and Immigration) 2 SCR 856 (1982) 864. See generally Guy Goodwin-Gill, International Law and the Movement of Persons Between States (Clarendon Press 1978) 75-87; Goodwin-Gill (n 35) 70; See also specific literature on this topic EW Vierdag The Concept of Discrimination in International Law (Springer 1973); WA McKean, 'The meaning of Discrimination in International \& Municipal Law' (1970) 44 BYIL 177; The substantive linkage to non-discrimination was recognized by the Canadian Supreme Court in Attorney-General v Ward 2 SCR 689 (1993). Goodwin-Gill (n 35) 70 (emphasis added).

International Convention on the Elimination of All Forms of Racial Discrimination (adopted 1 December 1965, entered into force 4 January 1969) UNTS 660195 (ICERD); See also UNHCR Handbook (n 38) para 68-70, for a description of this ground. The Handbook provides that 'race ... has to be understood in its widest sense to include all kinds of ethnic groups that are referred to as 'races'" "' in the common usage," para 68.

'After the National Party gained power in South Africa in 1948, its all-white government immediately began enforcing existing policies of racial segregation under a system of legislation that it called apartheid. Under apartheid, non-white South Africans (a majority of the population) would be forced to live in separate areas from whites and use separate public facilities, and contact between the two groups would be limited, hence leading to various uprisings against this form of persecution.' See generally History.com Editors, 'Apartheid' (A\&E Television Networks, 7 October 2010) <https://www.history.com/topics/africa/apartheid> accessed 11 May 2019.

In April 1994, 800,000 men, women, and children perished in the Rwandan genocide, perhaps. As many as three quarters of the Tutsi population were murdered by the Hutus due to allegations that they were the cause of the country's increasing social, economic, and political pressures. See generally 'Genocide in Rwanda' (United Human Rights Council) <http://www.unitedhumanrights.org/genocide/genocide_in_rwanda> accessed 11 May 2019. 


\section{ii. $\quad$ Nationality}

'Nationality', in this case, not only encompasses 'citizenship' but also refers to ethnic or linguistic groups and may, therefore, overlap with race.$^{50}$ This envisages the persecution, for instance, of a national of State B who is resident in State A, is driven out of the State of residence and is denied the protection of State B. Particularly prevalent is the right of a national to enter their own State.$^{51}$ It should be noted, though, that nationality as contained in Article 1(A )(2) of the 1951 Convention is 'usually interpreted loosely to include origins and membership of particular ethnic, religious, cultural and linguistic communities' ${ }^{52}$

\section{iii. Religion}

For a long time, religion has been the basis upon which communities have singled out others for persecution, for instance during the Holocaust. ${ }^{53}$ Religion itself can take different manifestations. ${ }^{54}$ As is the case with the other Conventional refugee grounds, it is the perception of the persecutor that is relevant. ${ }^{55}$

UNHCR Handbook (n 38) paras 74-76.

Goodwin-Gill (n 44) 101-103, 164-167.

Goodwin-Gill (n 35) 73; See also Directive 2011/95/EU of the European Parliament and of the Council of 13 December 2011 on standards for the qualification of third-country nationals or stateless persons as beneficiaries of international protection, for a uniform status for refugees or for persons eligible for subsidiary protection, and for the content of the protection granted [2011] OJ L337/9 art 10(1)@D which adds 'common geographical or political origins or [a group's] relationship with the population of another State'.

This was a systematic, bureaucratic, state-sponsored persecution and murder of six million Jews by the Nazi regime and its collaborators; Holocaust is a word of Greek origin meaning 'sacrifice by fire."' History.com Editors, 'The Holocaust' (A\&E Television Networks, 14 October 2009) <http://www.history.com/topics/world-war-ii/the-holocaust> accessed 11 May 2019.

Ajayi and Olushola Olayin v MCI FC IMM-5146-06 Martineau 2007 FC 594 (2007) the claimant alleged that her stepmother wanted to circumcise her and her father wanted to force her to participate in an initiation ritual. She also claimed a fear of supernatural powers and beings. The Court held that it was not patently unreasonable to conclude that the claimant had no objective fear of persecution. A person's' fear of magic or witchcraft can be real on a subjective basis, but objectively speaking, the State cannot provide effective protection against magic or witchcraft or against supernatural forces or beings from beyond. The State could concern itself with the actions of those who participate in such rituals but, in this case, the claimant testified that she did not fear her stepmother or father. See 'Chapter 4 - Grounds of persecution' (Immigration and Refugee Board of Canada) <https://irb-cisr.gc.ca/en/legal-policy/legal-concepts/Pages/RefDef04.aspx> accessed 11 May 2019.

See for instance Yang, Hui Qing v MCI FCTD IMM-6057-00) Dubé (2001) In this case, the claimant feared persecution by the authorities in China due to her adherence to Falun Gong beliefs and practices. The Court held that the CRDD should have found Falun Gong to be partly a religion and partly a particular social group. Applying the reasoning in Canada (Attorney General) v Ward 2 S.C.R. 689 (1993), para 73 regarding political opinion, the Court held that if Falun Gong is considered by the government of China to be a religion, then it must be so for the purposes of this claim. A question was certified regarding the scope of the term 'religion' used in the Convention refugee definition; however, it appears that no appeal was filed. 


\section{iv. Membership of a particular social group}

The 1951 Convention, in Article 33(1), together with Article 2 of the Universal Declaration of Human Rights, ${ }^{56}$ recognizes 'social' factors as potential avenues of persecution. The prohibition of the same can also be traced verbatim to Article 2 of the International Covenant on Economic, Social and Cultural Rights of 1966 and Article 26 of the International Covenant on Civil and Political Rights. Hathaway and Goodwin-Gill agree that this ground is open for development, as the term 'social group' is not defined in the travaux preparatoires of these Conventions ${ }^{57}$ Both authors go on to indicate that hist could mean groups defined by unalterable characteristics such as gender, sexual orientation or family affiliation, by past status such as class or caste or by voluntary association such as a union or students.

\section{v. Political Opinion}

A broad interpretation of political opinion is 'any opinion on any matter in which the machinery of state, government, and policy may be engaged' ${ }^{58}$ Persecution on the grounds of political opinion could be based on such factors as political party differences, feminism, ${ }^{59}$ domestic violence, ${ }^{60}$ union activity, whistle blowing or even neutrality. ${ }^{61}$

\section{c) Well-Founded Fear}

'Well-founded fear of being persecuted' is the most important phrase in the refugee definition. ${ }^{62}$ It embraces two elements of the definition: a subjective one of being 'well-founded' and an objective one of 'fear' ${ }^{63}$ While fear is a subjective emotion, ${ }^{64}$ the determination of refugee status requires that it must be well-founded, that is, it must have an objective basis. ${ }^{65}$ This bipartite test has been recognised, for instance, in Australia, where the High Court indicated that the 'well-founded fear' 'has both subjective and objective elements and necessitates consideration of the mental and emotional state of the individual and, also, the objective facts

Universal Declaration of Human Rights (adopted 10 December 1948) UNGA Res 217 A(III) (UDHR).

Goodwin-Gill (n 35) 74, 85; Hathaway and Foster (n 35) 50.

The word 'engaged' was interpreted in Femenia, Guillermo v MCI FCT.D IMM-3852-94) Simpson (1995). The claimants asserted that their political opinion was that they opposed the existence of corrupt police and advocated their removal and prosecution. They argued that this was an opinion on a matter 'in which the machinery of state, government and policy may be engaged."' Madam Justice Simpson concluded that the State is 'engaged' in the provision of police services, but not in the criminal conduct of corrupt officers. In her view, that was not conduct officially sanctioned, condoned or supported by the State and therefore, the claimants" asserted political opinion did not come within the Canada (Attorney General) v. Ward 2 S.C.R. 689 (1993), para 73 characterizations of political opinion. See Chapter 4 - Grounds of Persecution (n 53).

See Fatin v INS 12 F3d 1233 (1993).

See Matter of R-A- 24 I\&N Dec 629 (2008).

See Rivera-Moreno v. INS 213 F3d 481 (2000).

See UNHCR Handbook (n 38), para 37; See also Hathaway and Foster, (n 35) 91.

Hathaway and Foster (n 35) 91; See also UNHCR 'Advisory Opinion on the Interpretation of the Refugee Definition' (23 December 2004), para 6-7 this is in fulfilment of UNHCR 'Statute of the Office of the United Nations High Commissioner for Refugees' (14 December 1950) UNGA Res 428(V) annex para 8; See also UNHCR Handbook (n 38), para 38; See also, See UNHCR 'Interpreting Article 1 of the 1951 Convention relating to the Status of Refugees (April 2001), para 11.

Ibid.

Ibid. 
relating to the conditions in the country of their nationality. ${ }^{166}$ Canadian Courts have also adopted this approach. ${ }^{67}$

Basically, in claiming refugee status, one must substantiate their claim in order to fulfil the objective element of 'fear'. Also, 'fear is a forward-looking appraisal of risk' ${ }^{68}$ Hence, the issue is not whether the claimant had good reason to fear persecution in the past, but whether, at the time the claim is being assessed, the claimant has good grounds for fearing persecution in the future ${ }^{69}$ According to general principles of the law of evidence on matters of the burden of proof, 'he who alleges must prove' (emper necessitas probandi incumbit ei qui agit) - in the case of refugee claims, this means the asylum-seeker. This burden of proof (onus probandi) is discharged by providing a credible testimony and personal experiences which have given rise to the fear of persecution. However, because of the particularly vulnerable situation of asylumseekers and refugees, the responsibility to ascertain and evaluate the evidence is shared with the decision-maker. ${ }^{70}$

Furthermore, in evaluating the asylum-seeker's testimony, the applicant's fear should be considered well-founded if he/she 'can establish, to a reasonable degree, that his continued stay in his country has become intolerable $[\ldots]^{71}$ Lastly, for a claim of well-founded fear to be established, there must be 'a reasonable chance; a reasonable degree of likelihood; support by relevant factors such as human rights record of country of origin; the testimony of the claimant; past persecution and persons in similar situations. ${ }^{172}$ Hence, having already discussed the criteria that must be satisfied for one to be considered a refugee, the fundamental question then becomes: do climate migrants meet these criteria?

\section{Climate Migrants: Do they Meet the Criteria of the Refugee Defini- tion?}

There is no widely accepted definition of who an 'environmental refugee' is. The Climate Institute, however, defines climate migrants as, 'people fleeing from environmental crises, whether natural or anthropogenic events, and whether short or long term.' ${ }^{73} \mathrm{An}$ inability to gain a livelihood due to environmental degradation, natural disasters or development projects obligates climate migrants to migrate from their homelands. This must be distinguished from

Re Minister for Immigration and Multicultural Affairs; Ex parte Miah 206 CLR 57 (2001), para 62 per Gaudron J; See also J Hathaway and M Foster, (n 35) 92.

See Canada (Attorney General) v. Ward 2 S.C.R. 689 (1993), para 64; see also N'emeth v. Canada (Minister of Justice) 3 SCR281 (2010), para 98; See generally J Hathaway and M Foster, (n 35) 92.

Hathaway and Foster (n 35) 92.

Mileva v. Canada (Minister of Employment and Immigration) 3 F.C. 398 (1991) 404.

UNHCR Handbook (n 38), para 196; See also J Hathaway and M Foster, (n 35) 119; UNHCR Advisory Opinion (n 62), para 9.

UNHCR Handbook (n 38), para 42; See also UNHCR Advisory Opinion (n 62), para 10.

See J Hathaway and M Foster, (n 35) 113; See also Chan v. Canada, (n 42), para 120. The Canadian Court has also made clear that there is no substantive difference among the various formulations often employed to define well-founded fear, noting that what is required is "proof that there is a "reasonable chance," a "reasonable" "' possibility, or a "serious possibility"”' of being persecuted: Németh v Canada (Justice) 2010 SCC 56 (2010), para 98.

Climate Insitute: Environment and Security <http://climate.org/archive/topics/environmental- security/index.html> accessed $23^{\text {rd }}$ May, 2019. 
the concept of economic migrants. Economic migrants are people who have left their own country and seek, by lawful or unlawful means, to find employment in another country. ${ }^{74}$ For climate migrants, the reasons for their displacement include land degradation, drought, deforestation, natural disasters, and other environmental changes that interact destructively with poverty and population pressure. ${ }^{75}$

In lieu of the select definition above, it is paramount to consider an environmental refugee as per the definition and conditions enumerated in Article 1(A)(2) of the 1951 Convention, in order to ascertain whether they fit within that definition.

\section{a) Alienage: 'is outside the country of his nationality'}

As previously discussed, in order for one to be considered a refugee and enjoy the benefit of such status, they must have crossed an international border. ${ }^{76}$ Climate migrants are people fleeing from environmental crises, for example severe drought. These are people who, for one reason or another, must leave their 'natural habitat' and go to a neighbouring country for instance, in order to ensure their survival. As previously indicated, this form of departure does not require an external factor such as climate change to necessitate it; the key point is that one must cross an international border.

\section{b) Well-founded fear of persecution and the grounds thereof}

Having crossed an international border, the most difficult task for climate migrants is to prove persecution under the previously discussed grounds. As for race, climate migrants do not fall under this criterion, since the persecution is by the environment. With respect to nationality, they also do not fall under this criterion since the 'persecution' is not on account of their nationality of the State. They neither fall under the criterion of religion, nor the criterion of political opinion.

The question, therefore, is whether the grounds of persecution under the 1951 Convention are exhaustive or require expansion. The answer is not straightforward. This is because there is much concern that 'any expansion of the definition would lead to a devaluation of the current protection for refugees recognized by the Convention. ${ }^{17}$ Governments have a vested interest in keeping the refugee definition as narrow as it is because of the obligations they have to refugees; in this manner, any possible extension would result in reduced support for refugees. ${ }^{78}$

See Jeff Crisp and Damtew Dessalegne, 'Refugee protection and migration management: the challenge for UNHCR' (2002) UNHCR 1.

Norman Myers, Environmental Exodus: an emergent crisis in the global arena (Climate Institute 1995) 17. See also Sarah Reed, 'Environment and Security' (Climate Institute, August 2007) <http://climate.org/archive/topics/environmental-security/index.html> accessed 11 May 2019.

Goodwin-Gill (n 35) 63.

Petra Ďurková and others, 'Climate refugees in the 21st century' (2012) Regional Academy of the United Nations 3, 8-9.

Roger Zetter and others, 'Environmentally displaced people, Understanding the linkages between environmental change, livelihoods and forced migration' (2008) 1 Refugee Studies Centre <https://www.rsc.ox.ac.uk/publications/environmentally-displaced-people-understanding-the-linkagesbetween-environmental-change-livelihoods-and-forced-migration> 11 May 2019. 


\section{c) Membership of a particular 'social group'}

The term 'social group' is not defined in the travaux preparatoires of the 1951 Convention and other Human Rights Conventions that mention the term. ${ }^{79}$ This in and of itself makes it difficult to come to an internationally acknowledged consensus as to what the term really means. ${ }^{80}$ The UNHCR, on the other hand, has provided helpful guidance in defining a particular social group by stating that:

A particular social group is a group of persons who share a common characteristic other than their risk of being persecuted, or who are perceived as a group by society. The characteristic will often be one which is innate, unchangeable, or which is otherwise fundamental to identity, conscience or the exercise of one's human rights. ${ }^{81}$

It is generally accepted that a particular social group cannot be defined by the persecution to which it is subjected..$^{82}$ Whereas being a member of a particular social group is an essential element for one to be considered a refugee, the same has to be accompanied by a reasonable likelihood of persecution on a Convention ground. This is deduced to be a cumulative connection and not an alternative one. ${ }^{83}$

In this regard, can 'climate migrants' be considered part of a 'particular social group'? The answer would be in the affirmative. The UNHCR guideline on Membership of a Particular Social Group (MPSG) explains the 'social perception' concept by indicating:

If a claimant alleges a social group that is based on a characteristic determined to be neither unalterable nor fundamental, further analysis should be undertaken to determine whether the group is nonetheless perceived as a cognizable group in that society. So, for example, if it were determined that owning a shop or participating in a certain occupation in a particular society is neither unchangeable nor a fundamental aspect of human identity, a shopkeeper or members of a particular profession might nonetheless constitute a particular social group if in the society they are recognized as a group which sets them apart. $^{84}$

Goodwin-Gill (n 35) 74, 85; J Hathaway and M Foster, (n 35) 50.; See also J Hathaway and M Foster, Membership of a particular group: Discussion article No.4: Advance Refugee Law Workshop, International Association of Refugee Law Judges, Auckland, New Zealand, October 2002 (15(3) International Journal of Refugee Law 2003) 477. See also statement by J McHugh in Av Minister for Immigration \& Ethnic Affairs 190 CLR 225 (1997).

But, the UNHCR has submitted that the ordinary meaning of the term 'particular social group' 'contains no inherent limitation on the range of factors which can serve to distinguish a group of persons from society at large' See, UNHCR's Intervention: Islam (A.P.) v Secretary of State for the Home Department Regina v Immigration Appeal Tribunal and Another, Ex Parte Shah (A.P.)(Conjoined Appeals) (1999). UNHCR 'Guidelines on International Protection No. 2: "Membership of a Particular Social Group" Within the Context of Article 1A(2) of the 1951 Convention and/or its 1967 Protocol Relating to the Status of Refugees' (7 May 2002) HCR/GIP/02/02, para 11.

Islam $v$ Secretary of State for the Home Department; $R v$ Immigration Appeal Tribunal and Another, ex parte

Shah UKHL 20 (1999); NS (Social Group - Women - Forced marriage) Afghanistan CG UKIAT 00328 (2004), para. 53; C Querton, 'The Interpretation of the Convention Ground of 'Membership of a Particular Social Group' in the Context of Gender-related Claims for Asylum: A critical analysis of the Tribunal's approach in the UK' RLI 8; See also, UNHCR Guidelines on International Protection (n 79), para 11-13. Another, ex parte Shah UKHL 20 (1999) per Lord Hoffmann; UNHCR 'Guidelines on International Protection: Gender-Related Persecution' (2002), para. 2; Querton, (n 80) 8-9. 
Following the above explanation, it would seem that, for instance, if farmers who rely on the land for their food find themselves lacking food due to a famine, they may constitute a particular social group if, in their society, they are recognized as a group which sets them apart.

Hence, people in regions where climate change has induced their migration may, for all intents and purposes, be termed as people belonging to a particular social group. This is because, as deduced by the UNHCR, they may share a common characteristic other than their risk of being persecuted, or may be perceived as a group by society, for example pastoralists, farmers or people of one community living in a particular region. This characteristic is one that is innate, unchangeable, or which is otherwise fundamental to identity, conscience or the exercise of one's human rights, for example the right to food in a drought situation or the right to housing in a sinking island situation. The next section herein delves into the discussion of whether 'climate change' can be considered a 'Conventional persecutor'.

\section{Climate Change: An Agent of 'Persecution'?}

The concept of persecution, though not defined in international law, is central to the determination of refugee status. ${ }^{85}$ However, the Preamble to the 1951 Convention conveys the message that "persecution encompasses all serious violation of human rights. ${ }^{186}$ Furthermore, the travaux preparatoires of the 1951 Convention do not show whether its authors intended to include a requirement that a well-founded fear of persecution must emanate from the government or those perceived to be acting in its interest. ${ }^{87}$

As for the agents of persecution, the UNHCR Handbook provides that, apart from the authorities of a country, persecution can also emanate from 'sections of the population'. This elicits the view that 'persecution that does not involve State complicity is still, nonetheless, persecution',.$^{88}$

All in all, climate change seems not to have been provided for in the analysis of who 'agents of persecution' can be. The focus is more on State and non-State actors as agents of persecution and climate change does not fall under either of these two categories. Climate change has adverse effects on people and their property. People cannot live in houses where floods can sweep over them at any hour of the night; or can they live in areas where a famine threatens to wipe out an entire community. Hence, roughly 20 million climate migrants later, ${ }^{89}$ climate change is indeed making matters worse by increasing the intensity and frequency of evolved drivers of displacement such as droughts, floods and other extreme weather conditions. ${ }^{90}$

UNHCR 'Agents of Persecution - UNHCR Position' (14 March 1995), para 3; UNHCR Handbook (n 38), para 51; A Grahl-Madsen, (n 38) 193; Hathaway and Foster, (n 35) 182.

UNHCR Agents of Persecution (n 83) para 3.

ibid para 3.

ibid para 5; UNHCR Handbook (n 38) para 65.

Disasters displaced an average of 27 million people each year between 2008 and 2013. See 'Global Estimates 2014: People displaced by disasters' (2014) IDMC <http://www.internaldisplacement.org/publications/global-estimates-2014-people-displaced-by-disasters> accessed 11 May 2019.

UNHCR 'Climate Change and Displacement in the 21st Century' (Oslo, Norway, 5-7 June 2011) $<$ https://www.unhcr.org/protection/environment/4ea969729/nansen-conference-climate-changedisplacement-21st-century-oslo-6-7-june.html> accessed 11 May 2019. 
Climate change is a reality that the UNHCR has also recognized as being a threat in the evolving nature of refugee migration. ${ }^{91}$ It is estimated that, by 2050, 50 to 300 million people may be displaced for climatic reasons such as sea level rise, increased water scarcity, desertification, floods etc. ${ }^{92}$ Nevertheless, as climate change continues unabated, the 1951 Convention defines a refugee as a person with a genuine fear of being persecuted for membership in a particular social group or class. The environmental refugee - not necessarily persecuted, yet necessarily forced to flee - falls outside this definition. As such, climate change cannot be termed as a 'persecutor' per the Convention and climate migrants largely remain 'invisible' to the law, not recognized, not counted.

It is prudent to opine that times have changed, and the Conventional persecution grounds are slowly being replaced by evolving 'persecution' grounds, particularly with regard to phenomenon caused by climate change, such as floods, famine and sinking islands. It is about time that, as the world deals with climate change and develops agreements towards the same, climate migrants should be kept in mind. 'A rising tide lifts all boats. But, in the age of melting glaciers, that tide is an ominous threat driving more refugees to flee and, if ignored, swallowing humanity itself. ${ }^{93}$ It is time that climate migrants are unveiled from the cloak of invisibility and recognized by the law. The next section focuses on how to protect climate migrants and the challenges that lie therein.

\section{Protecting Climate Migrants Under International Law}

Climate change has seen a flurry of world-wide forums bid to tackle this 'force of nature'. As the situation is likely to become more pressing, it is vital to consider now the status of climate migrants and the need for their protection and, furthermore, to give meaning to the old English adage, that 'a stitch in time, save nine'.

The analysis here is aimed at showing that the paramount objective should not be a new refugee regime for environmental refugees, but a collective international effort for better international accountability, cooperation and feasible environmental protection standards. ${ }^{94}$

\section{V.I Situations of Climate Migrants}

In order to ascertain the existence of climate migrants, this article analyses the situations in Somalia and Tuvalu., particularly in relation to climate migrants.

\section{a) The Case of Somalia}

Apart from political instability, which has long been touted as the main reason that Somali citizens moved to Kenya as refugees, climate change has been a key player. Many Somali

"What we are now seeing are more and more people that are forced to flee because of lack of water, because of lack of food, because of extreme poverty and many of these situations are enhanced by climate change." António Gutteres, United Nations High Commissioner for Refugees

UNHCR 'Climate change and its possible security implications' (11 September 2009) UN Doc A/64/350.

Andrew Lam, 'The Rising Tide - Environmental Refugees' (2012) New America Media <http://newamericamedia.org/2012/08/the-rising-tide----environmental-refugees.php > accessed 11 May 2019.

M Stavropoulou, 'Drowned in definitions' (2008) Forced Migration Review 31, 11-12. 
were forced to leave their land due to years of insufficient rains and drought and set off in search of relief. ${ }^{95}$

Their movements saw them cross an international border and end up in northern Kenya, where the Dadaab refugee complex became their home. This is a camp with a capacity of 90,000, but at the time of their arrival in 2011-2012, became home to roughly 300,000 (mostly Somali) refugees. ${ }^{96}$ In the aftermath of the drought, famine, and flooding, another 152,000 Somali refugees made their way to Dadaab, ${ }^{97}$ which was at one point termed the world's biggest refugee camp. ${ }^{98}$

This, in effect, shows the ramifications of climate change and the migrations necessitated by harsh environmental conditions. However, with the lack of legal recognition, it would be difficult to accord climate refugees the same protection as Conventional refugees. In this regard, as rightly put by Nathan Thanki, 'as a matter of compassion, environmentally displaced people should be thought of at the very least conceptually as equally vulnerable compared to Conventional refugees. ${ }^{99}$ It is on this premise, and as a matter of personal opinion, that Kenya exercised its good neighbourliness to accept the climate migrants, because returning them would be a case of sending them back to their 'death'. ${ }^{100}$

\section{b) The Case of Tuvalu}

Tuvalu, a Carteret Island of Papua New Guinea, faces a number of climate change -related issues. Tuvalu's population of 11,000 is clustered together on 9 islands, comprising a total land area of 10 square kilometres. Its highest elevation is just 15 feet above sea level. ${ }^{101}$ Onefifth of Tuvalu's population have already left their homes to seek refuge on larger islands.

Complex situations such as coastal erosion, destruction of sea walls and inundation by saltwater means that most of the small gardens of swamp taro and vegetables upon which families depend for food are no longer fertile. ${ }^{102}$ The displaced communities are being moved to Bougainville. but most residents are unwilling to move due to the fear of losing their homes and culture. ${ }^{103}$

M Dahir and M Perry, 'A Famine We Made?' (2011) Time 38-41.

E Weir and others, 'Horn of Africa: Not The Time To Look Away' (2011) Refugees International <http://www.refintl.org/policy/field-report/horn-africa-not-time-look-away> accessed 11 May 2019.

'Somalia Famine and Drought Situation Report 19' (2011) OCHA <https://reliefweb.int/sites/reliefweb.int/files/resources/OCHA\%20Somalia\%20Situation\%20Report\%2 0No.\%2019_2011.10.25.pdf> accessed 11 May 2019.

Albert Kraler and others, "'Climate Refugees" - Legal and policy responses to environmentally induced migration' (2011) European Parliament <http://www.statewatch.org/news/2011/dec/ep-climate-changerefugees-study.pdf> accessed 11 May 2019.

Nathan Thanki, 'Somali 'climate refugees' in Kenya: a consideration and a suggestion' (2012) Earth in Brackets available at, <http://www.earthinbrackets.org/2012/04/28/somali-climate-refugees-in-kenya-aconsideration-and-a-suggestion/> accessed 11 May 2019.

Allan Mukuki, 'The refugee influx dilemma': Is Kenya at a crossroad' (2013) 11.

Cole Mellino, 'Meet the world's first climate change refugees,' (EcoWatch 2016) <http://ecowatch.com/2016/01/05/first-climate-refugees/> accessed 12 May 2019.

Ben Farell, 'Pacific islanders face the reality of climate change . . . and of relocation,' (2009) UNHCR $<$ https://www.unhcr.org/.../pacific-islanders-face-reality-climate-change-relocation.html> accessed 12 May 2019.

ibid. 
These communities are already facing the impacts of climate change, and their unique locations and more traditional livelihoods make them particularly vulnerable to the consequences. In spite of the numerous challenges, the New Zealand Immigration and Protection Tribunal allowed a Tuvaluan family to be granted refugee status despite being environmental immigrants. ${ }^{104}$ It must be noted that the tribunal's decision to let the family stay in New Zealand as permanent residents was not based on the impacts of climate change in Tuvalu. Indeed, the Tribunal deliberately refrained from making a finding on this point. ${ }^{105}$ Nevertheless, this is one of first cases in which the concept of climate migrants was adjudicated upon.

Further, in 2014, Teitiota's bid to become the world's first climate change refugee was rejected. The 37-year-old moved to New Zealand with his wife in 2007 after deciding that their life on the low-lying Kiribati Island of Tarawa was no longer sustainable because of rising seas. He sought leave to appeal the tribunal's decision at the High Court, but that was dismissed. ${ }^{106}$

Despite this dismissal, Justice John Priestley continued to make what was possibly the first legal recognition of climate migrants. He stated that, 'At a stroke, millions of people who are facing medium-term economic deprivation, or the immediate consequences of natural disasters or warfare would be entitled to protection under the Refugee Convention. ${ }^{107}$

While the appeal decision was based on purely humanitarian and discretionary grounds, as opposed to any domestic or international legal obligation, ${ }^{108}$ Justice Wild concluded the judgment by stating:

No-one should read this judgment as downplaying the importance of climate change. It is a major and growing concern for the international community. The point this judgment makes is that climate change and its effect on countries like Kiribati is not appropriately addressed under the Refugee Convention. ${ }^{109}$

It can be rightly deduced from the above statement that it is not that climate migrants should not be protected, but that the legal ground for protecting them is lacking at this point.

This conundrum, as faced by the New Zealand tribunal, therefore leads to the question: having confirmed that climate migrants indeed exist, can international law as it currently is used to protect them?

V.II Can climate migrants be protected under international law as it is? El-Hinnawi's 1985 report to UNEP provided the first known definition of climate migrants:

A Maas, 'Tuvalu climate change family win NZ residency appeal' (2014) NZ Herald <http://www.nzherald.co.nz/nz/news/article.cfm?c_id=1\&objectid=11303331> accessed 12 May 2019.

See Jane McAdam, 'No "Climate Refugees" in New Zealand,' (2014) Brookings <http://www.brookings.edu/blogs/planetpolicy/posts/2014/08/13-climate-refugees-new-zealandmcadam> accessed 12 May 2019.

See Kenneth Weiss, 'The Making of a Climate Refugee,' (2015) Foreign Policy $<$ http://foreignpolicy.com/2015/01/28/the-making-of-a-climate-refugee-kiribati-tarawa-teitiota/>.

Teitiota $v$ The Chief Executive of the Ministry of Business Innovation and Employment NZHC 3125 (2013 (emphasis added).

Jane McAdam (n 103). See also similar deliberations by New Zealand Tribunals and Courts $A F$ (Kiribati) NZIPT 800413 (2013); Teitiota $v$ The Chief Executive of the Ministry of Business Innovation and Employment NZHC 3125 (2013); Teitiota $v$ Chief Executive of the Ministry of Business, Innovation and Employment NZCA 173 (2014). Teitiota $v$ Chief Executive of Ministry of Business, Innovation and Employment NZCA 173 (2014) 41. 
Climate migrants are defined as those people who have been forced to leave their traditional habitat, temporarily or permanently, because of a marked environmental disruption (natural and/or triggered by people) that jeopardized their existence and/or seriously affected the quality of their life. By 'environmental disruption' in this definition is meant any physical, chemical and/or biological changes in the ecosystem (or the resource base) that render it, temporarily or permanently, unsuitable to support human life. ${ }^{110}$

This idea of climate migrants has been widely criticized by various scholars. The critics have termed it a 'mythical' concept rather than actual reality. They claim that their movement is necessitated by a myriad of other reasons and not from environmental change alone. These reasons include economic, social, institutional and political factors, combined with other harmful processes and events such as civil war and poverty. ${ }^{111}$

This criticism reflects a serious scepticism about the severity of the situation of people displaced by climate change, particularly because there are no uniform statistics to verify the existence of such displacement. ${ }^{112}$ The critics of the concept of climate migrants are more focused on the concept of 'persecution' as contained in the 1951 Convention. ${ }^{113}$ As discussed, this is where the 'rubber meets the road', because it is highly disputable that climate change can meet the threshold of persecution on the Convention grounds of race, religion, nationality, membership of a particular social group or political opinion.

Essam El-Hinnawi, Environmental Refugees (Nairobi, United Nations Environment Programme 1985) 4. E1Hinnawi's definition fails to distinguish between people displaced beyond the borders of their own state and internally displaced persons (unlike many definitions of 'refugees', including the Geneva Convention). For the purposes of this study, the focus is on those displaced beyond the borders of their own state.

For a general discussion on this see Richard Black, Refugees, environment and development (Longman 1998);

Richard Black, 'Environmental refugees: Myth or reality?' (2001) UNHCR <https://www.unhcr.org/research/working/3ae6a0d00.html> accessed 12 May 2019; Barbara Kavanagh and Steve Lonergan, 'Environmental degradation, population displacement and global security' (1992) Canadian Global Change Program 1; Gaim Kibreab, 'Migration, environment and refugeehood' In B. Zaba \& J. Clarke (eds), Environment and population change (Ordina Editions 1994); Gaim Kibreab, People on the edge in the Horn: Displacement, land use and the environment in Gedaref Region, Sudan (London, James Currey 1996); Gaim Kibreab, Environmental causes and impacts of refugee movements: A critique of the current debate (Disasters, 1997) 20-38; Shin Lee, 'In limbo: Environmental refugees in the third world' in N. P. Gleditsch (ed), Conflict and the environment (Kluwer Academic, 1997); Steve Lonergan, 'The role of environmental degradation in population displacement, in environmental Change and Security Program Report' (1997) 4 Woodrow Wilson International Center for Scholars, 5-15; J McGregor, 'Refugees and the environment' in Richard Black \& V Robinson (eds), Geography and refugees: Patterns and processes of change (Belhaven Press 1993), 157-170; Astri Suhrke, 'Pressure points: Environmental degradation, migration and conflict' (Chr. Michelsen Institute 1992); Astri Suhrke, 'Pressure points: Environmental degradation, migration and conflict' in L Reed (ed), Occasional article series of the project on environmental change and acute conflict (University of Toronto and American Academy of Arts and Sciences 1993), 3-31; Astri Suhrke, 'Environmental degradation and population flows' (1994) 47 Journal of International Affairs 473; Astri Suhrke and A Visentin, 'The environmental refugee: A new approach' (1991) 2 Ecodecision 73; WB Wood, 'Hazardous journeys: Ecomigrants in the 1990s' in D Conway and JC White (eds), Global change: How vulnerable are north and south communities? (Indiana Center on Global Change and World Peace 1995); WB Wood, 'Ecomigration: Linkages between environmental change and migration' in Migration policy in global perspective series occasional article no. 3, New York: The International Center for Migration, Ethnicity and Citizenship, 1996; WB Wood, 'Ecomigration: Linkages between environmental change and migration' in AR Zolberg and PM Benda (eds), Global migrants, global refugees (Berghahn 2001) 42. 
This begs the question of whether the 1951 Convention definition of a refugee can be expanded to include climate migrants. The answer to this would be a biased 'yes', and regional refugee conventions point towards this answer. In lieu of the various refugee definitions initially deduced from the various international and regional Conventions, it is evident that there has been a successful expansion of the definition of a refugee so as to cater for a wider range of refugees, such as political asylum seekers and people fleeing from internal and external aggression. This emergence of 'new' ${ }^{114}$ refugee situations necessitated special attention in different parts of the world. Therefore, the enlargement of the definition of a refugee is necessary so as to include and protect those new types of refugees arising from new situations, such as people fleeing from environmental disasters. ${ }^{115}$

To cast light on the definition in the OAU Convention, it introduces objective criteria for determining refugee status. These criteria are based on the conditions prevailing in the country of origin, and require 'neither the elements of deliberateness nor discrimination inherent in the 1951 Convention'. ${ }^{116}$ In this regard, people fleeing from floods, drought, hurricanes and sinking islands are fleeing from the 'environmental' 'conditions prevailing in their country of origin', just like political asylum seekers and those fleeing from external or internal aggression. All they need to rid them of the 'cloak of invisibility' is legal recognition.

Hence, just like the regional Conventions, it would be possible to expand the definition of a refugee to include people fleeing from climate change hazards. While this is more of a policy issue, it is one which can be led by the United Nations. This is because the United Nations is a key institution with the capacity to develop multilateral solutions to global problems and to defend and uphold the basic human rights of climate migrants, such as dignity and formal attention and protection. ${ }^{117}$

With more and more people fleeing their homes to save their lives as a result of environmental hazards, the words of Article 14 of the Universal Declaration of Human Rights come into play. :'Everyone has the right to seek and to enjoy in other countries asylum from persecution.' 118 While this 'spins' back the debate discussed previously, as to what exactly constitutes 'persecution' and whether climate change should be considered a 'persecutor', this is a discourse that can be undertaken 'more positively' by the various actors and agencies at the United Nations. This is so particularly in order to develop a policy to formally recognizes climate migrants within the existing international refugee protection framework.

This is a problem that is bound to worsen in the coming years. As the world discusses the effects of climate change in major conferences and summits, it should not forget the 'resultant casualties' of the same. Sooner or later, the number of climate migrants will swell to astronomical figures that will no longer elicit the debate as to whether they exist or not, but

The word 'new' is used to signify the shifting tide from 'conflict' related refugees as envisaged by the 1951 Convention, to new classes of refugees like political asylum seekers.

Livia Bacaian, 'The protection of refugees and their right to seek asylum in the European Union' (2011) 70 University of Geneva <https://www.unige.ch/gsi/files/6614/0351/6348/Bacaian.pdf> accessed 12 May 2019, 17.

Mandal (n 31). See also M Sharpe (n 31); Arbodela (n 31) 192.

Karen McNamara, 'Conceptualizing Discourses on Environmental Refugees at the United Nations' (2007) Population and Environment, 22.

Proclaimed by the United Nations General Assembly in Paris on 10 December 1948 General Assembly resolution $217 \mathrm{~A}$. 
that of how to protect them. In this regard, a brief discourse on how the European Court of Human Rights (ECtHR) has aimed to protect refugees in an even wider sense is important to put things into a judicial perspective. This will bolster the discourse on the expansion of the Convention definition.

\section{V.III ECtHR and the protection of refugees: Expanding the scope even further}

It has been noted by the UN General Assembly, through the Secretary General, that those who flee from environmental disasters such as famine may not be simply economic migrants since they are not moving out of choice. They are refugees from hunger. ${ }^{119}$ This means that 'they are fleeing out of a state of necessity, not out of choice'. ${ }^{120}$

In this regard, the ECtHR has expanded the scope of protection within Article 3 of the European Convention of Human Rights (ECHR), ${ }^{121}$ which provides for the prohibition of torture or inhuman or degrading treatment or punishment. This expansion has been seen, for instance, in the context of political asylum seekers. While the Court has agreed that the Convention and its Protocols does not provide protection to asylum seekers, ${ }^{122}$ it has gone further to provide protection to individuals 'where substantial grounds have been shown for believing that an individual, if expelled, would face a real risk of being subjected to treatment contrary to Article 3 [of the ECHR] in the country of origin. ${ }^{123}$

Hence, in the above instance, the ECtHR implied an obligation not to expel the person in question back to their country of origin. ${ }^{124}$ In this regard, the Court has undertaken an 'evolutive' interpretation of human rights, ${ }^{125}$ particularly in relation to refugees. An evolutive interpretation of the ECHR is the basis through which the Court keeps the meaning of human rights both contemporary and effective. ${ }^{126}$

It must be noted that, at the time of writing this article, there was no direct European case law that dealt with the issue of climate migrants. ${ }^{127}$ However, the ECtHR has, in a number of instances, ruled that a State must take appropriate measures to minimise the damage

Livia Bacaian (n 113) 19.

UNGA 'The right to food' OHCHR A/62/289 (22 August 2007) 20.

Convention for the Protection of Human Rights and Fundamental Freedoms (European Convention on Human Rights, as amended) (ECHR) art 5.

Vilvarajah and Others $v$ the United Kingdom Series A no 215 (1991) para 102.

This is relation to linking the definition of who a refugee is and the principle of non-refoulement. See Chahal v The United Kingdom 70/1995/576/662 (European Court of Human Rights (ECtHR), 15 November 1996) para 74.

Soering v the United Kingdom Series A no 161 (1989), para 90-91; Cruz Varas and Others $v$ Sweden Series A no. 201 (1991), para 69-70; Vilvarajah and Others v the United Kingdom Series A no. 215 (1991), para 103.

The principle of interpreting human rights in light of modern circumstances is established in the case of Tyrer $v$ The United Kingdom 5856/72 (ECtHR, 25 April 1978); The ECtHR considers the Convention to be a 'living instrument'.

Kanstantsin Dzehtsiarou, 'European Consensus and the Evolutive Interpretation of the European Convention on Human Rights' (2011) 12 German Law Journal 1730.

Finn Myrstad and Vikram Kolmannskog, 'Environmental Displacement in European Asylum Law' (2009) 11 European Journal of Migration and Law <https://doi.org/10.1163/157181609789804321> accessed 12 May 2019, 316. 
that may occur to its citizens. Failure to do so may, in more instances than not, result in a breach of the Convention. ${ }^{128}$ This is because a State, in that 'failure', will have failed to afford protection to its citizens. It is my opinion that this is the critical point in relation to climate migrants. If a State cannot protect its citizens from environmental harm (which is the case in most instances), then it is unable to afford protection to them in the Convention way. In this regard, if individuals who moved to other States, for example because of drought, were returned to the place they fled, in ECtHR terms this will be a violation of the principle of nonrefoulement, because the individuals will be subjected to inhuman or degrading treatment. This is taking into consideration that they are climate migrants for all intents and purposes.

Hence, it is evident that the ECtHR has taken a broad approach to Article 3 of the ECHR. It must be noted that, in as much as the scope of Article 3 ECHR is different from the Conventional scope of refugee protection, it is aimed at affording wider protection to a broad class of individuals who are not necessarily protected by the 1951 Convention. It is in this way that climate migrants can be afforded protection and be recognized legally. This will be made possible if climate change and hazardous environmental conditions are considered as actors of serious harm. ${ }^{129}$ The necessity of considering climate change as an actor of serious harm will go a long way towards ensuring that refugees are protected beyond the scope of the Conventional State and non-State actors. Although this is a concept that is seemingly not feasible at present with the current refugee situation, ${ }^{130}$ it is not impossible that it can be researched upon and a consensual international policy developed on this basis.

In lieu of the above approach by the ECtHR, it is prudent to discuss the feasibility of an entirely separate Convention for environmental refuges and the practicality thereof as suggested by some scholars. ${ }^{131}$

\section{Feasibility of a Separate Convention and the Challenges Thereof in Protecting Climate Migrants}

As indicated, my position on this topic is biased to the fact that creating a new convention would not be the best answer to the challenges that climate migrants pose to international law. This position is informed by the results of a ministerial meeting hosted by UNHCR in

Elefteriadis v Romania 38427/05 (ECtHR, 25 January 2011). See also Fadeyeva v Russia 55723/00 (ECtHR, 9 June 2005).

Adam Reuben, 'Environmental Refugees' and the possibility of subsidiary protection' (Keep Calm and Talk Law 2015) <http://kctl.uk/8h> accessed 12 May 2019.

AFP, 'Europe is thinking very carefully about what the refugee crisis is going to cost them' (2015) Business Insider UK <http://uk.businessinsider.com/afp-eu-to-weigh-economic-costs-of-refugee-crisis-20159? $\mathrm{r}=\mathrm{US} \& I R=\mathrm{T}>$ accessed 12 May 2019.

Dana Falstrom, 'Stemming the Flow of Environmental Displacement: Creating a Convention to protect Persons and Preserve the Environment' (2002) 13 Colombia Journal of International Environmental Law and Policy 1, 18; See also Roger Zetter, 'Protecting Environmentally Displaced Persons: Developing the Capacity of Legal and Normative Frameworks' (2011) Refugee Studies Centre, 16. 
December 2011, which shows how contentious the issue of environmental displacement still is with States and their reluctance to allow for such a discussion to take root. ${ }^{132}$

Falstrom proposes that a convention designed specifically for protecting environmentally displaced person would be a more feasible alternative. This scholar proposes that a new convention should be shaped in a similar way to the United Nations Convention against Torture of $1984 .{ }^{133}$ Her proposition is aimed at addressing both the cause of the problem (environmental issues) and the result (climate migrants). ${ }^{134}$

Falstrom asserts that this would provide temporary protection for environmentally displaced persons, as well as require States to take steps to remove the causes of such migration. ${ }^{135}$ However, and rightfully so, Falstrom does acknowledge that the creation of such a treaty would require a great deal of energy and time. ${ }^{136}$

Despite Falstrom's plausible suggestion, it has been criticised by authors who term today's politically charged environment as a key hindrance to the initiative. It does not give any hope of a global, rights-based and effective instrument. ${ }^{137}$ That is to say, States lack the political will required to negotiate a new instrument to protect climate migrants. ${ }^{138} \mathrm{~A}$ statement made in an interview by Jane McAdam with Saber Chowdhury MP, Member of the All Parliamentary Committee on Climate Change, Bangladesh, in Dhaka, 21 June 2010, puts this into perspective:

'I think the first thing, before you go into the protocols and structures, what I think is needed is political weight, whether the appetite is there for governments, especially in the developed world, the Annex I countries to address the issue in Bangladesh, because I think if you have that will, if you have that willingness, that acceptance ... then you can always work something out. I think one of the problems is that we're getting too involved in discussions on what sort of a structure we should have without first

UNHCR. 2011. 'Ministerial meeting' (2011) <http://www.unhcr.org/pages/4d22fd496.html> accessed 12 May 2019. See also Vikram Kolmannskog, 'Climate Change, Environmental Displacement and International Law' (2012) 24 Journal of International Development < https://doi.org/10.1002/jid.2888> accessed 12 May 2019,1078.

As with the Convention Against Torture, she suggests that states 'offer temporary protection to those fleeing from environmental problems, and also assume obligations and duties in order to solve these problems within their own jurisdictions, thus preventing the creation of environmental refugees from the start."' Her grounding is that such a Convention would require specific obligations from State parties to prevent the root causes from occurring. Dana Falstrom (n 129), 2 and 21. See also Aurelie Lopez, 'Protection of EnvironmentallyDisplaced Persons in International Law' (2007) 37 The Environmental Law, 402; Frank Biermann and Ingrid Boas, 'Preparing for a warmer world: towards a global governance system to protect climate refugees' (2010) 10 Global Environmental Politics, 60-88; David Hodgkinson and others, 'Copenhagen, climate change 'refugees' and the need for a global agreement' (2009) 4 Public Policy, 159; Bonnie Docherty and Tyler Giannini, 'Confronting a rising tide: a proposal for a convention on climate change refugees' (2009) 33 Harvard Environmental Law Review 349.

Falstrom (n 129), 2. See also Lopez (n 131) 402-403 and 408.

ibid 18.

ibid 23-26.

Vikram Kolmannskog and Lisette Trebbi,'Climate change, natural disasters and displacement: a multi-track approach to filling the protection gaps' (2010) International Review of the Red Cross; See also Jane McAdam, 'Swimming against the tide: why a climate change displacement treaty is not the answer' (2011) 23 International Journal of Refugee Law, 2-27; See also See Kolmannskog (n 130) 1078.

McAdam (n 135) 15-16. 
actually having the political will ... So, I think the Bangladeshi position is that first the countries have to accept the concept and once they accept it, then I'm sure we can find some sort of an adjustment. ${ }^{139}$

It is paramount that, firstly, the concept of climate migrants is standardised in a manner that all States accept. It would be from this point onwards that States would meet at the negotiation table with a meeting of the minds and not with divergent interests.

It should be noted that this concept of creating a new convention has been tried over and over again to no avail, in a bid to come up with a new treaty: ${ }^{140}$

1. UNFCCC Protocol on the Recognition, Protection, and Resettlement of Climate Refugees, ${ }^{141}$

2. Draft Convention on the International Status of Environmentally-Displaced Persons, ${ }^{142}$

3. Convention on Climate Change Refugees; ${ }^{143}$

4. A Convention for Persons Displaced by Climate Change; ${ }^{144}$

5. An additional protocol to the European Convention on Human Rights. ${ }^{145}$

At time of writing, resistance to accepting Conventional refugees within the borders of EU States, for example, due to their numbers, has been well documented. ${ }^{146}$ This then begs the question, if Conventional refugees find it difficult to acquire refugee status, how much more difficult will it be for climate migrants who will be governed by their own Convention?

In lieu of the above discourse, and in echoing McAdam's position, it would be more feasible to begin by developing regional soft law declarations on the protection of climate

ibid 16.

ibid 7.

Frank Biermann and Ingrid Boas (n 131) 60; see also, Frank Biermann and Ingrid Boas, 'Protecting Climate Refugees: The Case for a Global Protocol' (2008) 50 Environment Science and Policy for Sustainable Development 8; for criticism of their approach see M Hulme, 'Commentary: Climate Refugees: Cause for a New Agreement?' (2008) 50 Environment Science and Policy for Sustainable Development; For another UNFCC-based proposal see Angela Williams (n 2) 502.

Draft Convention on the International Status of Environmentally-Displaced Persons (CRIDEAU and CRDP, Faculty of Law and Economic Science, University of Limoges) (2008) 4 Revue Européene de Droit de l'Environnement 375. Article 2(2) defines 'environmentally-displaced persons' as 'individuals, families and populations confronted with a sudden or gradual environmental disaster that inexorably impacts their living conditions and results in their forced displacement, at the outset or throughout, from their habitual residence and requires their relocation and resettlement'. A 'right to resettlement' is elaborated in Article 9: States parties are to establish 'transparent and open legal procedures for the demand and grant or refusal of the status of environmentally-displace [sic] person based on the rights set forth in the present chapter'.

Docherty and Giannini (n 131) 349-350 and 373; Docherty and Giannini proposed an 'independent' or 'stand-alone' convention defining 'climate change refugee' and containing 'guarantees of assistance, shared responsibility, and administration'.

An Australian-based project also seeks to 'establish an international regime for the status and treatment of such persons.' 'A Convention for Persons Displaced by Climate Change' (2012) <http://www.ccdpconvention.com/index.html> accessed 12 May 2019.

Committee on Migration, Refugees and Population, 'Environmentally Induced Migration and Displacement: A 21st Century Challenge' (23 December 2008) Council of Europe Doc 11785, para 6(3) and 121.

Rick Lyman, 'Eastern Bloc's Resistance to Refugees Highlights Europe's Cultural and Political Divisions' (2015) The New York Times <http://www.nytimes.com/2015/09/13/world/europe/eastern-europemigrant-refugee-crisis.html?_r=0 > accessed 12 May 2019. 
migrants. ${ }^{147}$ Soft law is considered a new quasi-source of international law and it can be defined as 'normative provisions contained in non-binding texts, aimed at covering those weak provisions of international agreements not entailing obligations. ${ }^{148}$ This will provide a more feasible head-start for developing responses. A new international instrument on climate migrants would result in a debacle of the competing interests of all States in their different contexts. ${ }^{149}$

It has been argued that soft law can play an important role in consolidating existing norms into a clear and transparent understanding of the application of existing human rights norms to the situation of migrants of all kinds. ${ }^{150}$

In summation, as much as there is an urgent need to protect climate migrants, this article suggests that developing a whole new convention is not the answer, because of the highly politicised international environment. This is not to say that it is totally against such an idea. On the contrary, the idea is feasible but, as indicated earlier, this would be taking the 'long way round'.

Instead, expanding the refugee definition in the 1951 Convention is a viable position. But again, as shown above, this is an initiative that has been highly debated. The concept of judicial pronouncement has also been discussed but, aside from the New Zealand case law mentioned above, no court has yet determined the rights of climate migrants. The middle ground therein would be to develop soft law guidelines on the same. The aim of these guidelines would be to first consolidate and apply existing international human rights norms into sets of guiding principles for different groups, including climate migrants.

Further, these guidelines would improve mechanisms for inter-agency collaboration and thus ensure implementation of these norms and principles for the protection of different groups of refugees. This position would make it easier to affect an internationally agreeable policy change and an eventual definition change in the long run. This would, in effect, assist in sealing the 'refugee definition gap' by legally recognizing climate migrants.

\section{Conclusion and Recommendations}

In conclusion and as discussed, expanding the established refugee definition to encompass climate migrants would require a combination of political will from States and an acceptance of the concept. Further, the ECtHR has shown that a refugee, whether a political asylum seeker or a criminal facing the death sentence, is no less entitled to their basic rights and needs

Such as The Niue Declaration on Climate Change, Annex B to Forum Communiqué, 39th Pacific Islands Forum, Alofi, Niue, 19-20 Aug. 2008, Doc. PIFS(08)6. See Jane McAdam, (n 135) 26. See also Alexander Betts, 'Towards a Soft Law Framework for the Protection of Vulnerable Irregular Migrants' (2010) 22 International Journal of Refugee Law, 209.

Dinah Shelton (ed), Commitment and Compliance: The Role of Non-binding Norms in the International Legal System (OUP 2000) (emphasis added) 292.

Stefanie Grant, 'International Migration and Human Rights' (Global Commission on International Migration 2005) <https://c-faculty.chuo-u.ac.jp/ andyb/GM/GMHR/Grant\%202005.pdf> accessed 12 May 2019; Alexander Aleinikoff, 'International Legal Norms on Migration: Substance without Architecture' (2007) International Migration Law: Developing Paradigms and Key Challenges 467; Alexander Betts (n 145) 215. 
than their traditional counterparts. Hence, using human rights concepts to expand the refugee definition has a natural appeal. ${ }^{151}$

Hence, since judicial precedence has not pronounced the rights of climate migrants and political interests have taken centre stage on this issue, the UN, as the organized community of States, must take the lead on this issue. The UN must take it upon itself to develop a policy that formally recognizes climate migrants within the existing international refugee protection framework. This is best done, as suggested, via a soft law regime of guidelines. The author's recommendations towards this approach would be:

1. Definition of an Environmental Refugee

This would be the starting point in giving recognition to an environmental refugee in lieu of the ever-changing climate conditions. This would give credence and legal recognition to this type of refugee.

2. Standards of Protection

Identification of types and levels of protection should be made available to climate migrants on a humanitarian grounding. Which rights would be involved and what would be the content of the protection provided to climate migrants? These are central issues that the discussions on the standard of protection must address.

3. Concept of Burden-Sharing

As stated, it is estimated that there will be 200 million refugees by the year 2050 . This is by no means a small number. Hence, the concept of burden-sharing would be an important consideration because usually certain States are more overwhelmed with refugees than others. Refugees are a burden that is to be shared by the international community as a whole. In this regard, States should agree on a formula for sharing the burden in hosting them and not leaving it all to just a few developing States.

4. International Organisational Involvement and Responsibility International organisations such as the UNHCR and IOM, as well as NGOs, could be helpful in ensuring the implementation of soft law guidelines. It must be noted that the 1951 Convention lacks an implementation authority and, as such, that has made it difficult for the UNHCR to ensure compliance with the Convention. Soft law guidelines should be developed in a way to ensure that that concerned international organisations promote and ensure adherence by States to the guidelines' norms and principles. This will help in ensuring international cooperation and assistance in dealing with climate migrants.

The main assertion of this article is that, while it is paramount that the debate on the protection of climate migrants remains on the right track, the main objective should not be to create a new regime for their protection. The aim should be to rid the entire process of political interference and lack of consensus on the international arena, and to channel efforts towards better international accountability, cooperation, environmental protection and, finally, creating a feasible legal recognition of climate migrants. This should be done within the available frameworks of judicial pronouncements, amendment of the definition in the 1951 Convention or the establishment of soft law guidelines. These are easier solutions than the 'long way round' of a new convention. This would in essence require all States to look beyond their political stands, meet at the negotiation table and identify that, indeed, climate migrants are here with us, and determine what should be done to protect them. 
Re-Imagining the Concept of Forced Migration in the Face of Climate Change 98

$*$

www.grojil.org 